\title{
State-of-the-Art Reformation of Web Programming Course Curriculum in Digital Bangladesh
}

\author{
Susmita Kar ${ }^{1}$, Md. Masudul Islam², Mijanur Rahaman ${ }^{3}$ \\ Department of CSE \\ Bangladesh University of Business and Technology (BUBT) \\ Dhaka, Bangladesh
}

\begin{abstract}
For last 15 years universities around the world are continuously developing effective curricula for Web Engineering in order to create good opportunities for graduates to cope up with IT-Software industries. From this study we will show the gap between the skill requirements of IT-Software industries and universities' web course curricula. Also, we will provide a balanced and structured web course curriculum for any universities. Nowadays, there is a rapid development in webbased applications everywhere but most of our students are late bloomer in programming. So, to ease their difficulties in web sector we need a balanced web curriculum and effective teaching method. By this curriculum one can achieve an overall idea and a minimum view of web engineering which can be beneficial for them in further Web development. Students get a little knowledge in their university on Web Engineering because of the vastness of the contents and the small duration of semester. Our two-semester web course curricula will help them to overcome this problem. Two-semester web course curricula have a huge impact on achieving the minimum required skill in web development field in IT-Software industries. It will help to obtain most of the area of web related content also it will increase problem solving skill and versatile knowledge of web engineering in undergraduate life.
\end{abstract}

Keywords-Web engineering; web development; outcome based learning; CDIO; web course curriculum; web ecosystem; digital Bangladesh

\section{INTRODUCTION}

The world is in hype with internet and its broad technology. Almost every applications and digital concern is now webbased. Even, with the rapid development of internet most of the software system is now converting their services into web applications. If you want to develop any software, turn it into web system for accessibility. The capability of developing web applications has become a must-have professional skill for IT areas, exclusively for those who are graduates.

Since Digital Bangladesh program was launched in 2009 the government has been proactively chasing the digital wings in a full throttle. Aiming at transforming Bangladesh into digital economy by 2021 and knowledge-based economy in 2041 billion dollars projects are ongoing. Within 2023 almost $45000+$ government websites will be published for services. Also, we are introducing our IT expertise in a billion-dollar market place of IT industries [1].

However, this rapid changes and development requires a lot of engineering and merits. This is why many of our universities, institutes and training centers are creating awareness of importance of web application development. Offering web engineering courses is now a trend and musthave thing in computer science. The ACM and IEEE Computer Society have added web programming courses as electives to the CS curriculum in the new CS2013 [2]. Web programming has become a dominant programming model. Still in our country most of the curriculum seems like backdated and weak. In the beginning of 2006, the traditional computer science curriculum did not include web engineering courses [3]. Gradually, many web courses are being introduced in different semesters in various institutes' curriculum according to that generation's advancements. These courses are all about some web programming techniques, programming languages, procedures and web database driven applications. It appeared to be clear that, to develop web applications multiple levels of skill is required. But recent survey shows that, there are some standards and professional view of industries which are absent in our present universities' curriculum. These curricula and course contents should be made according to the requirements of updated web ecosystem. So, many changes are introduced in recent days to develop professionalism in web engineering but we need proper guidance from beginning of undergraduate life. The growing importance of web application development on computing education is a proof that we need a concrete web curriculum in university studies.

Therefore, this paper will have three-fold: 1) Summarize the survey result of recent IT-Software Job trends. 2) Academic curriculum status of web engineering in different universities in Bangladesh. 3) A proposed outcome-based Web course design with effective sociocultural teaching method.

\section{RELATED Works IN DEVElOPING AND TEACHING WeB PROGRAMMING COURSE}

In the beginning, computer science study didn't give enough priority in web engineering. Most of the world wide universities had no web courses except giving some basic knowledge of internet. Since 1990, Tampere, a web programming course, has been taught in University of Technology and that was updated in 2010 [4]. The University of Texas Pan American decided to offer web programming course from 2005 for undergraduates [3]. A simple web programming course for students was developed by Stepp, Miller, and Kirst which required no prerequisites [5]. Robert E. Noonan implemented an advanced web programming course that highlighted server-side programming, database interaction, 
and security [6]. Xusheng Wang updated a web programming course which is based on server-side techniques with PHP and MySQL [7] and in 2014 he proposed second web programming course which contains Web 2.0 technologies and CMS [8]. M. $\mathrm{J}$. Lantis in his paper presented a web editor as a development platform to teach HTML and client-side programming [9]. In 2011, Connolly proposed three-semester web course sequences which contained HTML, CSS, JavaScript, server-side programming, server-side frameworks, user experience, security, deployment, hosting, and web services topics [10]. But Robert revised the idea and made a single semester course model [11]. Francesco Maiorana from University of Catania designs a curriculum suited both for graduates and for a thirdlevel high school web programming course [12].

Based on different case studies and teaching experiences on web programming at undergraduate studies we can list the following issues where Liu in 2011 presented challenges and tools used [13], Laverty in 2011 point-outs the difficulties of an efficient delivery of a dynamic web development, databasedriven platform [14] Baatard in 2007, offered a course using the PHP language with security problems [15]. Moreover, Noonan in 2007, Wang in 2006 and Olan in 2009 announced a course fixated on server-side programming and database interaction [6][7][16]. Gousie in 2006 shows on an interdisciplinary method to teach web programming, graphics and design in a course [17]. Stepp in 2009, presented a web programming course suggested to instructors to introduce PHP from the beginning [5] and Adams in 2007 developed a Web project-oriented course [18]. Recently Chao in 2013, reviewed the usage of framework but which is not suggested in preliminary web programming courses [19]. These are the summary view of ongoing activities and suggestions of updating web curricula in various universities to achieve standard goal towards web development in undergraduate level.

\section{Motivation}

Web Engineering or Web development is a huge task. Various types of knowledge, tools and techniques are needed to complete this engineering. Several facts we need to consider for web programming are: analysis, design, UX/UI, backend system, framework, database, security and maintenance. But the main issue that we should consider is to develop practical web application for industries that could benefit our country because day by day our country is adapting digital technology and online services. That is why we will emphasis on academic view of web development and their pros and cons.

\section{STATE-OF-THE-ART IN IT-SOFTWARE JOB FIELD IN BANGLADESH}

In order to keep pace with recent trends, we need to find out the updated requirements of IT-Software job fields in our country. We have surveyed last two years' job requirements in IT industries.

\section{A. Inspection on Job Skill Requirements}

The survey contains 2018 and 2020's data from country's leading job site bdjobs.com. Basically, we searched for IT/Engineering category jobs and among them we took 150+ valid job circulars around the country.

We have filtered the specific web development jobs from hundreds of jobs. We found a total of 163 valid IT Jobs in September 2018 and 180 valid IT jobs in January 2020 posted in website. From there we have collected requirements and additional skill requirements concerned with web engineering mostly. The following skills we fetched there: HTML, CSS, UX/UI, JavaScript, JSON, jQuery, Angular, VueJs, Various Scripting Language, PHP, API, PHP Framework, Laravel, ASP.Net, Web Engineering Concepts, Digital Marketing, Oracle, MySQL/MSSQL, System Analysis, Problem Solving, Project Management and Content Management/ Documentation. Almost in every job these skills are introduced as must-have issues for any candidate. In Fig. 1, the sorted data chart shows that from the end of 2018 to beginning of 2020 the IT related jobs have increased. Also, in each job the following skills are essential according to the view of employer. From the chart we can easily figure it out that, client-side language is leading the web-software industries then the server-side language is taking the role parallelly. The necessity of HTML, CSS, JS, PHP, MySQL, Framework, Web Database Programming, etc. proves that these contents should have serious impact on our academic curricula.

\section{B. Expert's Viewpoints}

To develop one's web development skills and keep growing with time so many expert communities provide voluntary advices and tutorials in open web. The most renowned community that created a tentative solid developer roadmap for beginner is roadmap.sh [20]. They have shown an infographic view to find a set of charts demonstrating the paths that anyone can take and the technologies that one would want to adopt in order to become a frontend, backend or a devops [20]. Summarized view of the roadmap-2020 is shown below in Table I.

There is more of it but in short, any beginner web developer can have a tentative idea of how he/she should move towards the world of web engineering. This is a vast journey and in this competitive market there is too short time for preparing oneself. That is why we want to make a welldeveloped syllabus for academic students so that they can have a strong base on web programming field after their graduation. 


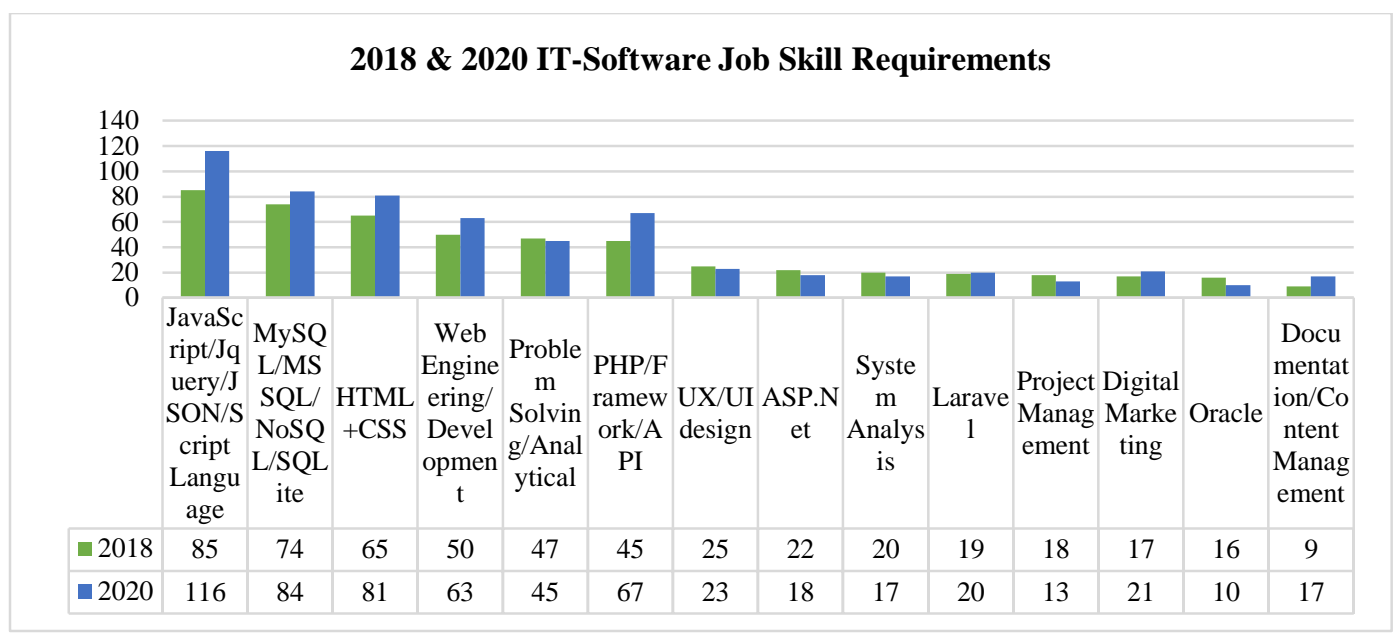

Fig. 1. 2018 \& 2020 IT Industries Skill Requirements.

TABLE. I. ROADMAP 2020 FOR WEB DEVELOPER

\begin{tabular}{|c|c|c|}
\hline Developer Type & Skills & Remarks \\
\hline \multirow{9}{*}{ Front-End } & Web Ecosystem, Internet and HTTP, Browser & Recommended \\
\hline & HTML, Standard Practices & Recommended \\
\hline & CSS, CSS3, Responsive Design & Recommended \\
\hline & JavaScript, DOM, API, Event Handling, Client-side actions & Recommended \\
\hline & Web Security, HTTPS, SSL & Learn Anytime \\
\hline & Modern CSS, Web Components, Templates, CSS Framework, UI Design, Tools & Better to Learn \\
\hline & Web Design Model, Server-side Rendering, Angular, Vue, React JS, GraphQL. & Better to Learn \\
\hline & Version Control, Git & Better to Learn \\
\hline & Mobile Application, Desktop Application, Web assembly & Learn Anytime \\
\hline \multirow{11}{*}{ Back-End } & Web Ecosystem, Internet and HTTP, Browser & Recommended \\
\hline & Basic Front-End Knowledge, HTML, CSS, JS & Recommended \\
\hline & Basic Networking Concepts and OS Knowledge & Better to Learn \\
\hline & Java, PHP, C\#, ASP.Net, Python & Recommended \\
\hline & Version Control, Git & Better to Learn \\
\hline & Relational Database, Query Language, SQL Engine, NoSQL, Normalization, Indexing & Better to Learn \\
\hline & APIs & Better to Learn \\
\hline & Web Security, Caching, Encryption, SSL & Recommended \\
\hline & Unit, Functional and Integration Testing & Better to Learn \\
\hline & Web and Database Server, Apache, IIS & Recommended \\
\hline & Web Sockets & Learn Anytime \\
\hline
\end{tabular}

\section{PRESENT CONDITION OF ACADEMIC CURRICULUM OF UNIVERSITIES OF BANGLADESH}

In 2020 we inspected more than 50 public and private universities which have engineering or IT related program. As per their current course curricula given in their official websites, we have collected 19 public and 14 private universities' course curricula of Computer Engineering or Information \& Telecommunication Program.

\section{A. Academic Inspection of Various Universities}

Among these 33 universities here is the chart view of present condition according to the online survey shown in Fig. 2.

\section{B. Limitations of Course Contents}

According to our survey, we have some major findings on course syllabus of web programming. If we compare the available 14 curricula from both private and public universities the private universities' syllabus are richer and more updated. Public universities still contain generic and backdated contents in their course structure. Most of the web courses are introduced in 4 th year and the basic prerequisite for the web courses are mostly programming and database. We have attached our findings in appendix [see Table IV in Appendix below]. 


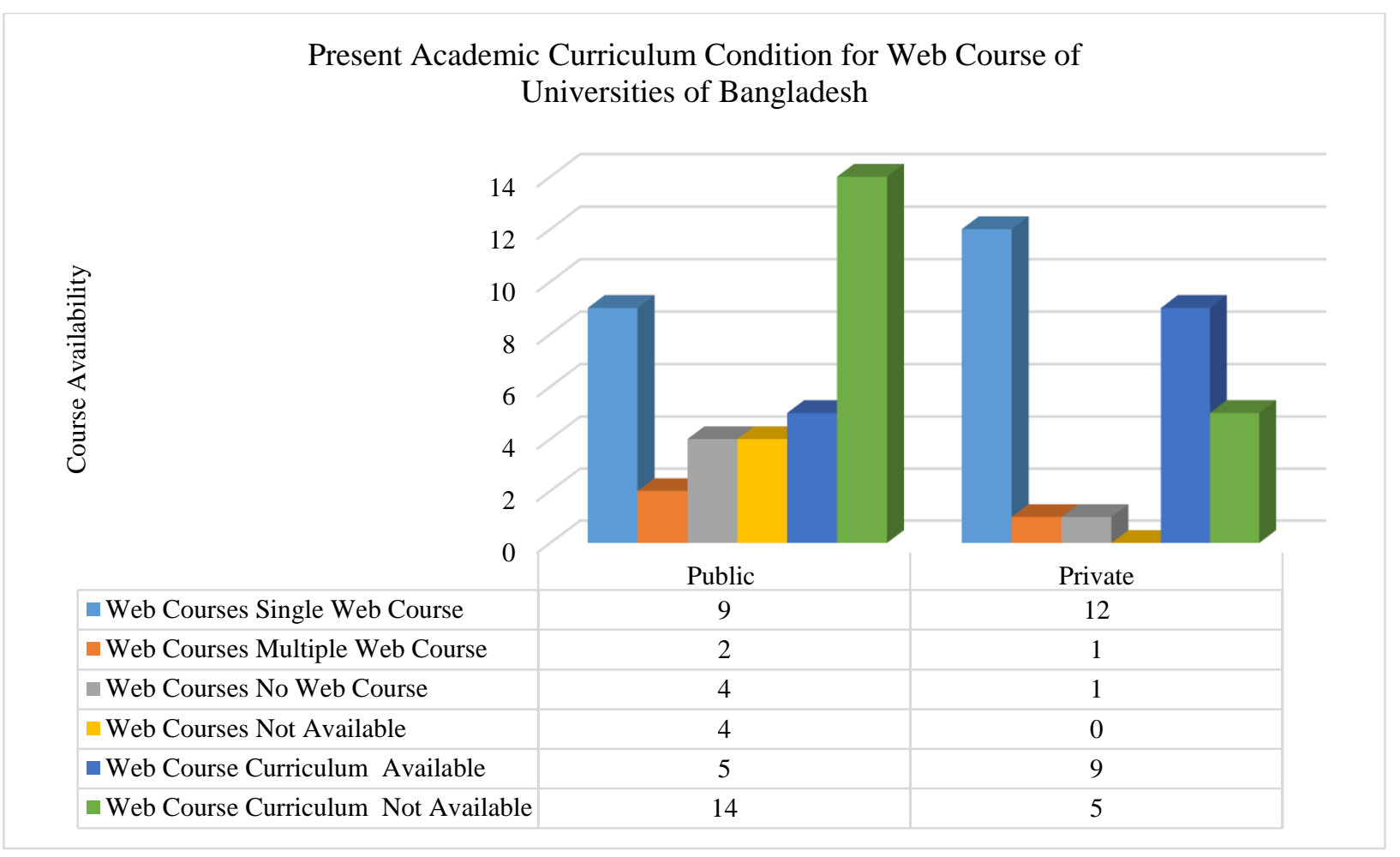

Fig. 2. Present Academic Curriculum Condition for Web Course of Universities of Bangladesh.

\section{ISSUES AND CHALLENGES TOWARDS THE WEB ECOSYSTEM}

Because of some limitations of old-style syllabus in computer engineering and IT-Software program, many undergraduate apprentices do not have a prospect to thoroughly learn web programming. Also, because of the high demands of job industries, many students are now leaning web programming. That is why improvised curriculum and learning method are needed to get something effective.

Nowadays, having simple static website is not enough for any company, institute or person. The success lies under the digital contents and the usage of modern tools and technologies within the website to make it riches in order to make anyone's business successful. Hence, modern web ecosystem contains the followings: Content Management, Google analytics (or another analytics program), Clean, modern design using cascading style sheets for page layout, Secure login area (for updating content and for developing an intranet/extranet), Social media tie-ins to Facebook, linked in and twitter, etc. [21] As Vanessa Fox said, "Your online strategy is your business strategy". Let us discuss some important web related issues that will clear our understanding that how it relates to our proposed web course syllabus. Website usability, a user investigation in 2004 ("Web usability - the main rules", 2004) shows that about $40 \%$ of users never come back to a website after their first unsuccessful attempt [7]. One of the worst web designer's mistakes is to create a website without a previous analysis of user needs [7]. Accessibility, the World Wide Web Consortium (W3C) defines a website as accessible if it allows access to people with disability (W3C, 2005). Privacy, the privacy of many web visitors is jeopardized due to data collecting on pages especially when the GET method of form submission is used, as it is known for its privacy vulnerabilities, and visitor tracking through cookies and web beacons [7]. Security, Hackers commonly use website vulnerabilities, and information related to them can be found on the Internet. Therefore, it is important to be informed about the vulnerabilities of company web application [7]. These are some fundamental issues that should be taken seriously during web development.

On the other hand, during the teaching web programming it faces many challenges. Web application is a complex, multifaceted execution model, so focusing a single technology and performing a depth-oriented approach does not work for web programming [22]. For example, there are many design tools \& technologies for instructor to teach front-end and back-end part such as HTML5, CSS3, Angular JS, Ruby on Rails, Bootstrap, Zend, Laravel, PHP, Python, API etc. It is tough for instructors to update their course contents always according to the rapid changes of web technologies and its features. The third challenge is inadequate integration among current web technologies and inconsistent implementation of standards [23]. Inconsistency between web browsers adds to the complexity of development, and these difficulties are reflected in the curriculum of web programming [24]. After reviewing the issues of web ecosystem and challenges of teaching web programming, we decided to focus on the objective to redesign the web course curriculum.

\section{VII.PROPOSED PEDAGOGICAL CURRICULUM}

According to ACM Curriculum Guidelines for Undergraduate Degree Programs in Computer Science 2013, there should be an elective web programming course which 
will cover basic web programming languages, some platform rule regulations, cloud technologies, following the web standards. After completion of the course one should be able to design and develop simple dynamic website with knowing proper constraints. They can also differ between software programming and web programming and identify how web standards impact on software development [25]. With all these things in mind we have designed two semester course.

Previously as we have seen recent job skill requirements in IT-Software industries it is clear that our Web programming syllabus must have two parts in a row: 1) Front-end part with templating; and 2) Back-end part as well as framework driven system.

So, we proposed two different courses in our academic curricula for web programming: 1 . Web Programming I (Frontend) 2. Web Programming II (Back-end). We have shown the practical part of the course contents. Before introducing our course model, we need to understand what is Outcome-Based (OB) curriculum and then we will provide a well-developed web programming course syllabus which are mapped with outcome-based system because most of the university in our country are grabbing the Outcome-Based Education (OBE) system gradually to get international recognition.

\section{A. Outcome based Web Curriculum}

There are different aspects of Outcome Based (OB) curricula. The four-basic principle [26] of OBE are: Curriculum should have clear focus, designing curriculum with clear definition, Curriculum should arise high expectation of achievement, expand the opportunities for different learners. Based on these principles we propose two semester web programming courses. Each semester may be 4 months (max. 13 weeks) or 6 months (max. 19 weeks) in length but the core contents will be the same. Where course contents for 4 months' semester will be short and minimal on other hand content for 6 months' semester will be broad and elaborated.

Another important fact is due to the limitation of time duration, vastness and complexity of web contents. It's not necessary to cover all the topics in these two courses. Therefore, we design a syllabus that will enough to give an abstract idea of web application based on web ecosystem. We will follow the division technique shown in Fig. 3.

At a glance, in Table II, Web Programming-I curriculum (Front-End) part there will be basic idea and concepts for web 2.0 technologies, update design language HTML5, CSS3 and the most widely used and required scripting language JavaScript/jQuery. These contents should be taught and assign by problem-based strategy. After learning this tools student will be able to create single page static web design such as ID Card, single page resume and registration/login page with client-side validation in JS or online order form. They will investigate the problem and design proper solution through real life experiences. There is also a little bit of introduction of design framework such as Bootstrap, Material Design and responsive design in order to conceive the device-oriented design. Finally, the student will be given a small group project which contains usage of all these tools \& technologies usages and show the demonstrations to their instructor. These curricula will cover a large area of their state-of-the-art of front-end development learning for students.

Moreover, In Table III, Web Programming-II (Back-End) Curriculum part there will be basic concepts of web server, installation, troubleshooting and security. Student will learn most widely used back-end language PHP and query language MySQL for a short period. As we know, CRUD (Create, Retrieve, Update \& Delete) process is core of any web development, so we have added problem-based CRUD programming along with file upload and dynamic CRUD system in our syllabus. Model View Controller (MVC) model and latest prominent framework Laravel basic is also introduced in our syllabus. Finally, the students will make a back-end structure for their previously designed web project with simple admin panel where all of these back-end tools and technologies usage are met.

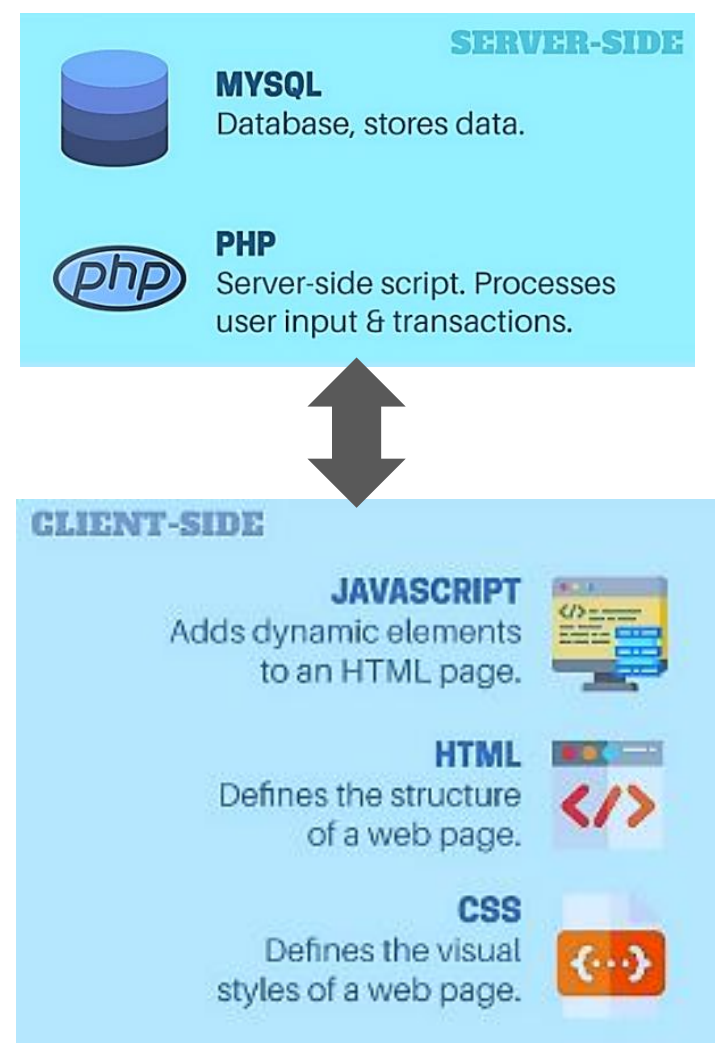

Fig. 3. Web Application Division Technique. 


\section{B. Web Programming-I (Front-End)}

TABLE. II. FIRST Web COURSE SyLlabus FOR Front-END PART

\begin{tabular}{|c|c|c|}
\hline Week & Topics & Strategy \& Learning Experience \\
\hline $1^{\text {st }}$ & $\begin{array}{l}\text { Web } 2.0 \text { fundamentals, HTTP, Web Standards, HTML, CSS, JS, DOM, Media Files, Browsers, } \\
\text { IDE, Tools \& Environmental setup. }\end{array}$ & Discussion, Overview \& Concepts \\
\hline $2^{\text {nd }}$ & $\begin{array}{l}\text { HTML } 5 \text { elements, Attributes, styles, link, list, image, table, block, class, id, iframe, heading, } \\
\text { comments. }\end{array}$ & Discussion, Assignment, Problem Based Learning \\
\hline $3^{\text {rd }}$ & HTML 5 Basic Form design, Input, Radio button, Select Box, Checkbox, Files, Canvas, Media. & Discussion, Assignment, Problem Based Learning \\
\hline $4^{\text {th }}$ & CSS 3 syntax, usage, Box Model, various selector, options, styling text, layout, typography. & Discussion, Assignment, Problem Based Learning \\
\hline $5^{\text {th }}$ & CSS 3 Animations, effects, border, media types, responsive design & Discussion, Assignment, Problem Based Learning \\
\hline $6^{\text {th }}$ & $\begin{array}{l}\text { JavaScript basic syntax, Object, DOM, alert \& dialogue box, various functions, events, Regular } \\
\text { Expression, validations. }\end{array}$ & Discussion, Assignment, Problem Based Learning \\
\hline $7^{\text {th }}$ & jQuery Basic, Object, Selector, Events, methods, API usage. & Discussion, Assignment, Problem Based Learning \\
\hline $8^{\text {th }}$ & jQuery form validation, animations, Get, Set, Add, Remove, traversing. & Discussion, Assignment, Problem Based Learning \\
\hline $9^{\text {th }}$ & $\begin{array}{l}\text { Make Static Web Page using HTML5, CSS3(Personal single page CV, ID Card, Routine } \\
\text { design), }\end{array}$ & Project \& Inquiry Based Learning, Demonstration \\
\hline $10^{\text {th }}$ & $\begin{array}{l}\text { Make simple Form Design using HTML5, CSS3, JS validation (Online Registration Form, } \\
\text { Online Login form, Pre-Book Order Form, Survey Form) }\end{array}$ & Project \& Inquiry Based Learning, Demonstration \\
\hline $11^{\text {th }}$ & $\begin{array}{l}\text { Introduction to Front-End Framework, Material Bootstrap, Installation, files structure, Syntax \& } \\
\text { Functionality }\end{array}$ & Discussion \& Concepts \\
\hline $12^{\text {th }}$ & Grid Layout, Typography, icon, Responsive design, navigations, Modal, Card, tables, form. & Discussion, Assignment, Problem Based Learning \\
\hline $13^{\text {th }}$ & $\begin{array}{l}\text { Make Mini Project: Simple portfolio pages: Menu, Banner, main content body, contact form, } \\
\text { embedded map, footer. }\end{array}$ & $\begin{array}{l}\text { Group Project Based Learning, Group Assignment, } \\
\text { Demonstration }\end{array}$ \\
\hline
\end{tabular}

C. Web Programming-II (Back-End)

TABLE. III. SECOND Web COURSE Syllabus For BACK-END PART

\begin{tabular}{|l|l|l|}
\hline Week & Topics & Strategy \& Learning Experience \\
\hline $\mathbf{1}^{\text {st }}$ & Web server installations, Configuration, Create Database and PHP files. & Discussion, Troubleshooting \& Demonstration \\
\hline $\mathbf{2}^{\text {nd }}$ & PHP Basic syntax, commenting, variable, Super Global Variable, loop, array. & Discussion, Assignment, Problem Based Learning \\
\hline $\mathbf{3}^{\text {rd }}$ & PHP functions, date time, include, file read write, session, cookies, MySQL connection. & Discussion, Assignment, Problem Based Learning \\
\hline $\mathbf{4}^{\text {th }}$ & Basic MySQL syntax, create table, insert, update, delete, joining, design database. & Discussion, Assignment, Problem Based Learning \\
\hline $\mathbf{5}^{\text {th }}$ & CRUD: PHP-MySQL form value insertion, multiple value insertion in Database & Problem Based Learning, Demonstration, Assignment \\
\hline $\mathbf{6}^{\text {th }}$ & CRUD: PHP-MySQL show lists data from database, searching data, deletion data values. & Problem Based Learning, Demonstration, Assignment \\
\hline $\mathbf{7}^{\text {th }}$ & CRUD: PHP-MySQL update database values by selection. & Problem Based Learning, Demonstration, Assignment \\
\hline $\mathbf{8}^{\text {th }}$ & Upload single and multiple files, photos in PHP-MySQL & Problem Based Learning, Demonstration, Assignment \\
\hline $\mathbf{9}^{\text {th }}$ & PHP-MySQL, Ajax dynamic data insertion, deletion, show. & Problem Based Learning, Demonstration, Assignment \\
\hline $\mathbf{1 0}^{\text {th }}$ & Basic concepts of Model View Controller (MVC), Architecture, example. & Discussion, Overview \& Concepts \\
\hline $\mathbf{1 1}$ & $\begin{array}{l}\text { th } \\
\text { login operation in PHP-MySQL }\end{array}$ & Project \& Inquiry Based Learning, Demonstration \\
\hline $\mathbf{1 2}^{\text {th }}$ & Basic concepts of Framework, Laravel installation, files structure, syntax, architecture. & Discussion, Overview \& Concepts \\
\hline $\mathbf{1 3}^{\text {th }}$ & Mini Project: Simple Admin Panel for personal portfolio website. & $\begin{array}{l}\text { Group Project Based Learning, Group Assignment, } \\
\text { Demonstration }\end{array}$ \\
\hline
\end{tabular}

\section{Evaluations in CDIO Method}

We will follow the CDIO (Conceive, Design, Implement and Operate) which is "learning by doing or project education \& learning" [27] to evaluate our proposed syllabus. Because Chen \& Fu showed in their paper how CDIO method improved Web development courses significantly [28]. In this method, instructor will plan how to show the teaching content through simple problem-based project. They will examine, design, develop and run the project and student will follow them from the beginning to the end. They may have out-of-class discussion or activity through group assignment. Also, during the session instructor can modify the problem and throw variety of problem to the students. Finally, by developing group project the students will have complete idea of how to use all these chunks of web tool \& technological knowledge into combined one and they will develop creativity, teamwork and interpersonal communication skills. 


\section{CONCLUSION}

We have presented an outline for what we believe should form a web engineering curriculum. It may seem a vast syllabus but any instructor can resize the contents based on the categories. These are the minimum view of contents that should appear in any web development programming courses. It contains a simple introduction of front-end and back-end tools \& technologies which are mostly required in web related job filed shown in Fig. 1. In order to improve our country's university education, we believe these two course curricula of web engineering can help a lot. Also, there are many scopes of improvement in this proposed a curriculum for web engineering. There may be new contents to be added or removed to adapt latest technologies or we may divide this syllabus into three semester courses to provide enough time to teach and learn.

\section{ACKNOWLEDGMENT}

I would like to thank Mr. Mizanur Rahman, Front \& Backend expert developer from Bangladesh University of Business $\&$ Technology of his extraordinary support and professional opinion to build these course curricula.

\section{REFERENCES}

[1]. "https://www.daily-sun.com/post/407497/2019/07/15/Digital Bangladesh--a-Story-of-Transformation" The Daily Sun, Web. 15th June 2019.

[2]. Ironman Draft, "ACM/IEEE-CS Joint Task Force on Computing Curricula 2013”, ACM-IEEE Society, 2013.

[3]. Xusheng Wang, "A Practical Way to Teach Web Programming in Computer Science". Journal of Computing Sciences in Colleges (2006): 211-220.

[4]. Tuomas Turto, Tommi Mikkonen "A Course on Web Programming". Proceedings of the 1st International Educators' Day on Web Engineering Curricula WECU (2010): $10 \mathrm{p}$.

[5]. Stepp, M., Miller, J., and Kirst, V. A "'CS 1.5" introduction to web programming', Proceedings of the 40th ACM technical symposium on Computer science education. (2009): 121-125.

[6]. Noonan, R. E. "A course in web programming", Consortium for Computing Sciences in Colleges, Journal of Computing Sciences in Colleges Vol. 22 (2007): 23-28.

[7]. Wang, X., A practical way to teach web programming in computer science, Consortium for Computing Sciences in Colleges, Journal of Computing Sciences in Colleges, Vol. 22 (2006): 211 - 220.

[8]. Xusheng Wang, "Design, Develop and Teach the Second Web Programming Course in Computer Science Curriculum". Journal of Computing Sciences in Colleges (2014): 52-59.

[9]. Lantis, M. J. "Using a web editor as a development platform for teaching HTML and client-side programming in the internet 101 course nifty tools and assignments", Journal of Computing Sciences in Colleges (2008): 97.

[10]. R. W. Connolly "Awakening rip van winkle: modernizing the computer science web curriculum", ITiCSE '11: Proceedings of the 16th annual joint conference on Innovation and technology in computer science education (2011):18-22.

[11]. Robert F. Dugan, "A single semester web programming course model”. Journal of Computing Sciences in Colleges (2013): 26-34.

[12]. Francesco Maiorana, "Teaching Web Programming an Approach Rooted in Database Principles". 6th International Conference on Computer Supported Education (2014): 49-56.

[13]. Liu, Y., Phelps, G. "Challenges and professional tools used when teaching web programming". Journal of Computing Sciences in Colleges, Vol. 26 (2011): 116-121.

[14]. Laverty, J. P, "Implementing a dynamic database driven course using LAMP”. Information System Education Journal (ISEDJ), Vol. 9 (2011): $33-40$.

[15]. Baatard, G. "Teaching PHP with security in mind". In Proceeding of the 5th Australian Information Security Management Conference (2007): 21-27.

[16]. Olan, M., 2009. Web applications: a test bed for advanced topics. Journal of Computing Sciences in Colleges, Vol. 24, No. 3, pp. 72-80.

[17]. Gousie, M. B., "A robust web programming and graphics course for non-majors". ACM SIGCSE Bulletin, Vol. 38 (2006): 72-76.

[18]. Adams, D. R. "Integration early: a new approach to teaching web application development". Journal of Computing Sciences in Colleges, Vol. 23 (2007): 97-104.

[19]. Chao, J., Davey, B. "Navigating the Framework Jungle for Teaching Web Application Development". Issues in Informing Science and Information Technology (2013): 95-109.

[20]. https://roadmap.sh, Developer Roadmaps. Web. 2020.

[21]. http://www.availdata.com/modern-Websites.cfm, AvialData. Web. 2012.

[22]. Verbyla, J., Roberts, G., "Web technology as curriculum". Proceedings of the 3rd Australasian conference on Computer science education (1998).

[23]. Rode, J., "Nonprogrammer web application development". Conference on Human Factors in Computing Systems (2005): 1055 - 1056.

[24]. Yi Liu, Gita Phelps. "Challenges and professional tools used when teaching web programming". Journal of Computing Sciences in College. Vol-26 (2011): 116-121.

[25]. Ironman Draft, “Computer Science Curricula 2013”, ACM-IEEE Society, 2013.

[26]. "http://cei.ust.hk/teaching-resources/outcome-based-education/ institutional-resources/obe-principles-and-process". Center for Education Innovation. Web. 2016.

[27]. S. Qiu, "The Application of CDIO Education Mode in the Teaching of Java Language Programming", Modern computer, Vol-9, (2011): 21-24.

[28]. Zhang-bin Chen \& Long-tian Fu, "Reform and Exploration of Webbased Training Course Teaching Based on CDIO Mode". 4th International Conference on Education and Social Development (2019). 
APPENDIX

TABLE. IV. FINDINGS

\begin{tabular}{|c|c|c|}
\hline University Lists & Web Course & Contents \\
\hline IIT, University of Dhaka & 1 & $\begin{array}{l}\text { Introduction to Html, Java Script \& CSS, Server-Side Programming: HTTP Server, Application Server, } \\
\text { MVC Web Framework, Web Services, Database Access: Object Relational Mapping, Lambda } \\
\text { Expression, Language Integrated Query, Data Reader, Writer, Web Security: Denial of Service, Buffer } \\
\text { Overflow, Cross Site Scripting, Authentication and Access Control }\end{array}$ \\
\hline CSE, University of Dhaka & 1 & N/A \\
\hline University of Rajshahi & 0 & N/A \\
\hline $\begin{array}{l}\text { Bangladesh University of } \\
\text { Engineering \& Technology }\end{array}$ & 0 & N/A, \\
\hline University of Chittagong & 0 & N/A \\
\hline Jahangirnagar University & 0 & N/A \\
\hline $\begin{array}{l}\text { Shahjalal University of } \\
\text { Science and Technology }\end{array}$ & 1 & N/A \\
\hline Khulna University & 1 & $\begin{array}{l}\text { Internet and World Wide Web } \\
\text { Applications, HTML, SGML, CGI } \\
\text { Programming, Active Server Page } \\
\text { Programming, Electronic } \\
\text { Commerce, Internet Database, } \\
\text { Javascript, VB Script, PHP, } \\
\text { ASP.NET, Jquery, XML } \\
\text { Programming, Flex, WCF, WPF, } \\
\text { AJAX, MVC, Silverlight, CMS, } \\
\text { Cold Fusion, Python, Mobile web } \\
\text { applications. }\end{array}$ \\
\hline $\begin{array}{l}\text { Hajee Mohammad Danesh } \\
\text { Science \& Technology University }\end{array}$ & 2 & N/A \\
\hline $\begin{array}{l}\text { Mawlana Bhashani Science } \\
\text { and Technology University }\end{array}$ & 2 & $\begin{array}{l}\text { Introduction to the Internet, the web, web } 2.0 \text { and Ajax, browser basics, XHTML, cascading style } \\
\text { sheets (CSS), JavaScript, Dynamic HTML, XML, RSS, building Ajax-enabled web application, } \\
\text { Macromedia Flash, Adobe }{ }^{\circledR} \text { Flex TM, Macromedia } ® \text {, Dreamweaver } ® \text {, web servers (IIS and } \\
\text { Apache), database: SQL, MySQL, DBI and ADO.NET 2.0, web services, PHP, Ruby and Ruby on } \\
\text { Rails, ASP>NET, web forms and web controls, JavaServer Pages web applications, Perl and CGI } \\
\text { (Common Gateway Interface), etc. }\end{array}$ \\
\hline $\begin{array}{l}\text { Patuakhali Science and } \\
\text { Technology University }\end{array}$ & 1 & $\begin{array}{l}\text { HTML, CSS, JavaScript, Joomla } 2.5 \text { and WordPress, PHP,MySql .It is valuable to both beginners and } \\
\text { advanced developers that already have experience in developing web applications. }\end{array}$ \\
\hline $\begin{array}{l}\text { Noakhali Science and } \\
\text { Technology University }\end{array}$ & N/A & N/A \\
\hline $\begin{array}{l}\text { Rajshahi University of } \\
\text { Engineering \& Technology }\end{array}$ & N/A & N/A \\
\hline $\begin{array}{l}\text { Khulna University of } \\
\text { Engineering \& Technology }\end{array}$ & 1 & N/A \\
\hline Jagannath University & 1 & N/A \\
\hline Comilla University & 1 & $\begin{array}{l}\text { Browser and Web Document. Static, Active and Dynamic pages, Programming paradigms and Web } \\
\text { programming. Object-oriented vs. Object-based programming, What should and should not be } \\
\text { programmed on the Web, Tasks suitable for programming on the Web, Choice of programming } \\
\text { language for Web programming. JavaScript for Web Programming: Introduction to the Language, } \\
\text { JavaScript: Object Hierarchy and working with objects, JavaScript: Event-Driven Programming, } \\
\text { Common Gateway Interface (CGI): Definition, Characteristics, CGI Programming Mechanism: GET } \\
\text { and POST methods, Simple examples using Perl, Introduction to PHP Programming Language. PHP } \\
\text { for Web Programming }\end{array}$ \\
\hline $\begin{array}{l}\text { Jessore University of } \\
\text { Science \& Technology }\end{array}$ & N/A & N/A \\
\hline $\begin{array}{l}\text { Pabna University of } \\
\text { Science and Technology }\end{array}$ & N/A & N/A \\
\hline $\begin{array}{l}\text { Bangladesh University } \\
\text { of Professionals }\end{array}$ & 1 & N/A \\
\hline North South University & 1 & $\begin{array}{l}\text { The course develops an in-depth knowledge of the concepts, principles and implementation techniques } \\
\text { related to the Internet and web technology. Details about the Internet, Intranet, Extranet, and e- }\end{array}$ \\
\hline
\end{tabular}




\begin{tabular}{|c|c|c|}
\hline & & $\begin{array}{l}\text { commerce will be covered. Topics include Web server management, threats, security of client and } \\
\text { server, network security like firewall, SSL, etc., authentication and authorization, legislation, privacy } \\
\text { and IP act, electronic payment, e-business, search engine, Internet protocols like TCP/IP, SGML, XML. } \\
\text { Design and development of Web applications using Java Applets, ASP, Java Script, CGI and other Web } \\
\text { tools is discussed. }\end{array}$ \\
\hline $\begin{array}{l}\text { University of Science and } \\
\text { Technology Chittagong }\end{array}$ & 1 & N/A \\
\hline Independent University & 2 & $\begin{array}{l}\text { Essential topics such as OSI \& TCP/IP architecture, Internet Routing, IP addressing \& Domain Name } \\
\text { System will be covered. Discussions will be held on popular browsers, HTML and Cascading Style } \\
\text { Sheet, HTTP, HTTPS, FTP, Client and Server side scripts, Scripting (JavaScript, AJAX, XML) with } \\
\text { jQuery libraries, Web Servers (IIS, Apache). Students will learn to design dynamic websites using } \\
\text { ASP.NET with SQL server and PHP with My SQL. A brief overview of topics in web security such as } \\
\text { cryptography, digital signatures, digital certificates, authentication \& firewall will be provided. }\end{array}$ \\
\hline $\begin{array}{l}\text { American International } \\
\text { University-Bangladesh }\end{array}$ & 1 & $\begin{array}{l}\text { Introduction and Practical use of HTML \& XHTML; Introduction and Practical use of XML; } \\
\text { Introduction and Practical use of XSL, \& XSLT; use of XQuery, \& Schema; XPATH, \& XLINK; use } \\
\text { of JavaScript; use of PHP; Database Connectivity with PHP; XML use with ASP.NET. }\end{array}$ \\
\hline $\begin{array}{l}\text { Ahsanullah University of } \\
\text { Science and Technology }\end{array}$ & 1 & $\begin{array}{l}\text { Introduction to Internet technology: Word Wide Web (WWW), Web pages, Web servers, HTTP, } \\
\text { HTTPs, FTP, Electronic mail, Search engines, Global databases, digital libraries, video on demand, } \\
\text { streaming audio and video; Web page design: HTML and DHTML concepts, tags, commands, form } \\
\text { design, table design, online request, dynamic functions, buttons, animations and multimedia, Script } \\
\text { languages, Embedding scripts in HTML; Intranet: Usefulness of intranet, Sharing scarce resources over } \\
\text { intranet, Network chatting and newsgroups; E-Commerce: Paying money over the network, Online } \\
\text { shopping cart, Mobile payment system; Web Security: Privacy Policy, Encryption techniques, Network } \\
\text { security and firewalls. }\end{array}$ \\
\hline Dhaka International University & 0 & N/A \\
\hline East West University & 1 & $\begin{array}{l}\text { Web Fundamentals, Programming Languages for the Web, } \\
\text { HTML Basics and the working environment, } \\
\text { Fundamentals of PHP language, } \\
\text { HTML with PHP, forms, sessions,cookies, etc., } \\
\text { CSS and templates, } \\
\text { Database manipulation in PHP, } \\
\text { Programming the browser and forms withJavaScript, } \\
\text { Dynamic programming using Asp.net, } \\
\text { AJAX basics,DHTML, } \\
\text { Security pitfalls and basic solutions, } \\
\text { Lab exercises, } \\
\text { Mini project }\end{array}$ \\
\hline University of Asia Pacific & 1 & $\begin{array}{l}\text { Introduction to web server and web programming, } \\
\text { introduction to any scripting language (such as PHP, JSP), Configuring } \\
\text { web server, HTML and Scripting language Tags, Statements and Whitespace web programming, } \\
\text { Comments, Functions, Variable Types and } \\
\text { Operators, Control Flow, Arrays, HTML forms, Retrieve data from form } \\
\text { elements using Get and Post Methods, String Manipulation, Database } \\
\text { Connection, Executing SQL queries, Session Control and Cookies, File } \\
\text { Handling. }\end{array}$ \\
\hline BRAC University & 1 & $\begin{array}{l}\text { A survey of current Internet technologies and state-of-the-art web programming methods. Using } \\
\text { client/server structures, topics studied will be drawn from JavaScript, JSP, ASP, Cold Fusion, Flash, } \\
\text { Document Object Model, HTML, Cascading Style Sheets, XML, CGI, TCP/IP and the .NET platform. } \\
\text { Programming tools may include PERL, various UNIX shell scripts, Windows batch files, Java and } \\
\text { other languages as needed. }\end{array}$ \\
\hline Manarat International University & 1 & N/A \\
\hline Daffodil International University & 1 & N/A \\
\hline Green University of Bangladesh & 1 & N/A \\
\hline $\begin{array}{l}\text { Bangladesh University of } \\
\text { Business and Technology }\end{array}$ & 1 & $\begin{array}{l}\text { Basic design and implementation of websites, Discussion of different navigation and organizational } \\
\text { strategies, Client-side technologies including HTML5, CSS, JavaScript, JSON, and JQuery, Server-side } \\
\text { technologies emphasizing implementations in PHP, Back-end data management, Interfacing Internet to } \\
\text { a database. Querying a database using Cold Fusion, Security issues, Emerging technologies }\end{array}$ \\
\hline $\begin{array}{l}\text { University of Liberal } \\
\text { Arts Bangladesh }\end{array}$ & 1 & $\begin{array}{l}\text { Designing an Internet utilizing a range of different technologies. Simplifying the creation and updating } \\
\text { web content. Expanding Intranet services by adding client-slide and server-side processing. Interfacing } \\
\text { Internet to a database. Querying a database using Cold Fusion. }\end{array}$ \\
\hline
\end{tabular}

